\title{
Developing English Syllabus for Pharmacy Students
}

\author{
Edi Suwandi ${ }^{1}$, Khoirul Wafa ${ }^{2}$ \\ edisuwandi@unugiri.ac.id \\ 1,2 English Education Department, NU Sunan Giri University, Bojonegoro, Indonesia
}

Received: 04 October 2020 Accepted: 29 November 2020

DOI: $10.24256 /$ ideas.v8i2.1598

\begin{abstract}
Starting with the Hutchinson and Walter (1994:18) that said if ESP is an approach to language learning based on the students' need. Moreover, knowing the reason for the students learn English is the fundamental reason. As the writer's experience to teach English in Pharmacy Unugiri Bojonegoro that there was no developed syllabus based on the students' need but only based on the lecturer' experience and knowledge. This research was at knowing the students' need and developing it to English in pharmacy syllabus. The procedures are to break down, to depict the purpose for the syllabus, to choose the syllabus type, to compose the syllabus content, to validate the created syllabus with the expert, to assess and redesign the syllabus. The subject of this study were fifty students of the second semester of the pharmacy program at Unugiri Bojonegoro that consist of 44 female and 6 male students and an English lecturer. Besides that some questioners were given to the students. The result of this study shows that if the students need the topics that related their future career and real life in their environment. The last result for this research is English in Pharmacy syllabus for bachelor students of Pharmacy program at Unugiri Bojonegoro.
\end{abstract}

Keywords: English for Specific purpose (ESP), English in Pharmacy, syllabus redesigning. 


\section{Introduction}

English is one of the compulsory subjects in the school as well as higher education. In this case, the students learn English which has correlation with their field. Thus, they study English as their necessity to develop their skill for their future career. In the other hand, they study English in specific purpose (ESP).

Related with the previous, Smock (2003) defines that ESP is a form of English instruction to through the fundamental of students' actual, immediate needs who must perform real life tasking, by not focusing on passing the examination or test in the end of the learning. His statement presents that ESP gives more appropriate students' need.

Furthermore, Saragih (2014) conducted her study to evaluate the needs of 50 nursing students in learning English. The result of this study showed that the real needs of nursing students in ESP which reflect for their future career. Also, P'Rayan (2008) was conducted his study to analysis the needs of learners of ESP, especially English for Engineering at Anna University, India. The finding of this study showed that the learners' productive skills have been ignored since the majority of the ESP classes were conducted in teacher oriented method. Furthermore, he suggested to redesign the objective and the syllabus properly.

The current ESP syllabus had been adapted from the several syllabus in pharmacy program in Indonesia. The syllabus consists of the topics or themes based on the communicative approach. As we know that, most of the lecturers sometime used English grammar and sentence pattern are central aspects of the learning and teaching. But the result of the analysis, the students need English speaking for communicative in their life as well as their career. According to Richardson (2001), there are two kind of tasks which can be claimed as the basis in designing a tsk-based syllabus: pedagogical task and real-word task. Real-word tasks are designed for the pupils who can be practicing and turn out to be important and useful in the real word (Richardson: 2013)

Based on the previous explanation, the writer concluded that if the lecturer in Pharmacy program, NU Sunan Giri Bojonegoro used syllabus structural and it was not appropriate for them. This can be serious problems that should be solved sooner. So that why the writer made research question "what English syllabus does the students' Pharmacy of NU Sunan Giri need'?

\section{Method}

As this study is carried out to improve teaching syllabus, research and development (R\&D) is the required research design of the study. Research and development (R\&D) is a review that creates and validates education items such as textbooks, Instructional media,teaching system, curriculum, etc. (Borg and Gall, 1983). Gall. Moreover, Latief (2012) describes research and development as research plan for the creation of educational items such as syllabus, curriculum, textbooks, educational media, modules, assessment. R\&D produces an educational 
commodity, in other words. In this study, the final outcome is ESP Syllabus used for study program of pharmacy in NU Sunan Giri University.

The writer used ADDIE model in this research.This model is an acronym which stands for Analysis, Design, Development, Implementation, and Evaluation. Several numbers of considerations affected the writer to adopt this model. The first, it provides simple procedure in designing or developing English syllabus for the Pharmacy College Students. The second, every single step in the model is clearly stated in which the writer knows what he should do in designing or developing syllabus. It is started to evaluate the students' needs. Finally, this model has two types of evaluations which can assess the effectiveness and the quality of the syllabus being developed (Castagnolo, 2008). The evaluations are in the forms of formative and summative evaluation.

The subject of this research were all of the students in pharmacy program, NU Sunan Giri University of second semester. All of the student are native speaker of Bahasa Indonesia and have been learning English since junior high school to senior high school. The students in bachelor degree of pharmacy program are 50 students.

The writer used interviewed and questionnaire as the instrument. The instrument gave to the 50 students who were still studying at the campus of NU Sunan Giri Bojonegoro. The interview has given for both students and lecturer, where the writer chose 5 students randomly who were still studying and a lecturer. The interview test to support the data from questionnaire. The questionnaire used to identify the students' need in pharmacy program

Several questions were distributed to all of the students in Pharmacy English teaching material and to design appropriate syllabus. The data from the interview and questionnaire were analyzed by descriptive qualitative.

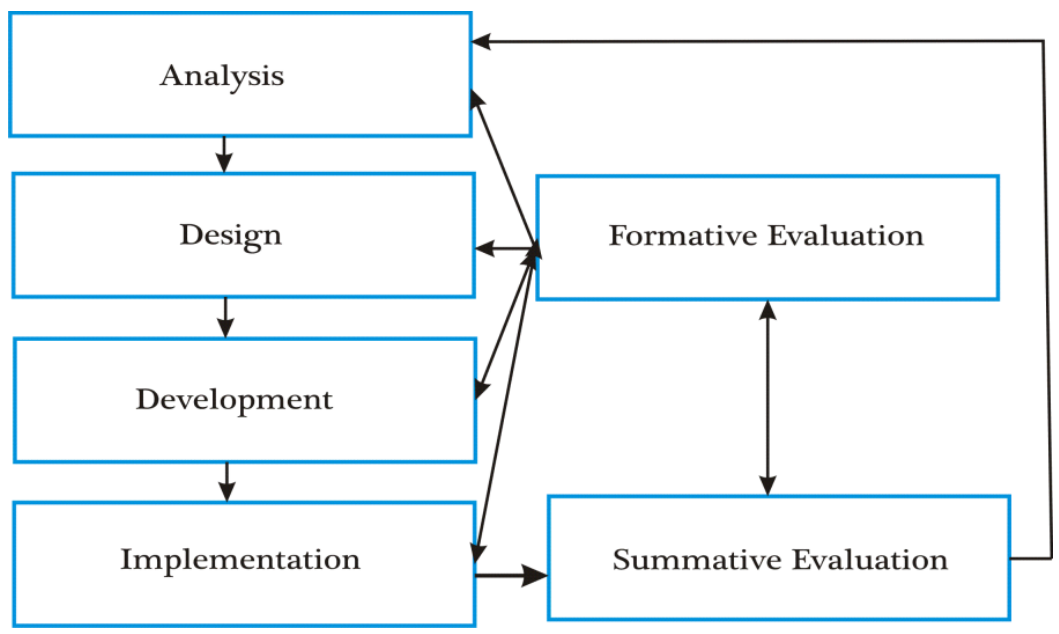




\section{Result}

The findings of this study are presented in the following tables below. Table 1 shows the personal information of the respondent

\begin{tabular}{|c|c|c|c|c|c|}
\hline & & & & Frequency & Percent \\
\hline \multirow{2}{*}{\multicolumn{2}{|c|}{ 1. Gender }} & \multicolumn{2}{|l|}{ Female } & 44 & $88 \%$ \\
\hline & & \multicolumn{2}{|l|}{ Male } & 6 & $12 \%$ \\
\hline \multirow[t]{2}{*}{2.} & Studied English (for Pharmacy) & \multicolumn{2}{|l|}{ Yes } & 50 & $100 \%$ \\
\hline & previously & \multicolumn{2}{|l|}{ No } & - & - \\
\hline \multirow[t]{2}{*}{3.} & Effort to improve English & \multirow{2}{*}{\multicolumn{2}{|c|}{$\begin{array}{l}\text { Yes } \\
\text { No }\end{array}$}} & 36 & $72 \%$ \\
\hline & & & & 14 & $28 \%$ \\
\hline \multirow[t]{4}{*}{4.} & Frequency of practicing English & \multicolumn{2}{|l|}{ Not at all } & 8 & $16 \%$ \\
\hline & & \multicolumn{2}{|l|}{ 1-2 hours } & 26 & $52 \%$ \\
\hline & & \multicolumn{2}{|l|}{ 3-5 hours } & 14 & $28 \%$ \\
\hline & & $\begin{array}{l}\text { More than } \\
\text { hours }\end{array}$ & 5 & 2 & $4 \%$ \\
\hline
\end{tabular}

Based on the result of questionnaire gave to the students about the personal information, the table 1 above shows the respondents' information. The dominant of the respondent is female (88\%). One hundred percent said that they have been studied English for Pharmacy, however 14\% students did not effort to improve their English. For frequency of practicing English, only 16\% that never practicing English in outside of campus or work, while the students have practiced English for one to five hours per week around $84 \%$.

Table 2 illustrates what the students identified as their length and weaknesses their English proficiency.

\begin{tabular}{llllc} 
Skills & Very weak & Weak & Fair & Good \\
Listening & $12.2 \%$ & $31.7 \%$ & $46.3 \%$ & $9.8 \%$ \\
\hline Reading & - & $12.2 \%$ & $24.4 \%$ & $63.4 \%$ \\
\hline Speaking & - & $17.1 \%$ & $56.1 \%$ & $26.8 \%$ \\
\hline Writing & $9.8 \%$ & $24.4 \%$ & $39 \%$ & $26.8 \%$ \\
\hline
\end{tabular}

Based on the result of questionnaire gave to the students about their length and weaknesses in English proficiency, the table 2 shows there are two skills that students difficult to study such as "listening (12.2\%) and writing (9.8\%)". However, for the four skills of English, listening has lower percentage only (9.8\%) in good and higher skills in reading is $63.4 \%$ in the same level.

Table 3 ranks the Pharmacy activities that the respondent think as important

\begin{tabular}{ll} 
Activities/Skills & $\begin{array}{c}\text { Students of } \\
\text { Pharmacy }\end{array}$ \\
\hline Social skills & $90 \%$ \\
\hline Interaction with colleague & $100 \%$
\end{tabular}


Edi Suwandi, Khoirul Wafa

Developing English Syllabus for Pharmacy Students

\begin{tabular}{|ll|}
\hline Administering medication & $70 \%$ \\
\hline Giving advice & $100 \%$ \\
\hline Report writing & $75 \%$ \\
\hline Presentation skills & $100 \%$ \\
\hline Giving instruction effectively & $90 \%$ \\
\hline Inquiring skills & $65 \%$ \\
\hline Reading and interpreting report & $80 \%$
\end{tabular}

Based on the result of questionnaire gave to the students about the activities during classroom, the table 3 presents that skills communication are fundamental skills that students need than others. There are two kinds of activities that all of the students' respond in $100 \%$ like interaction with the colleague and presentation skills. Inquiring skills is the lowest respond from the students of pharmacy that has only $65 \%$. Overall, most of the students need speaking skill that related with their career around $90 \%$.

Table 4 illustrates the topics that interesting to them and want to be included in the ESP course

\begin{tabular}{|l|l|}
\hline Topics & $\begin{array}{c}\text { Students of } \\
\text { Pharmacy }\end{array}$ \\
\hline Body parts & $85 \%$ \\
\hline Giving medicine & $100 \%$ \\
\hline Asking and reporting health problems & $90 \%$ \\
\hline Pronunciation and description of medicine & $60 \%$ \\
\hline Giving directions & $80 \%$ \\
\hline Explain medicine to client & $100 \%$ \\
\hline Sharing observation & $80 \%$ \\
\hline Starting presentation & $100 \%$ \\
\hline Giving instruction for medicine & $100 \%$ \\
\hline General duties of Pharmacy & $100 \%$ \\
\hline Description of time and date. & $100 \%$ \\
\hline Obtaining personal data for admitting patients & $90 \%$ \\
\hline Explanation diet programs to clients & $95 \%$ \\
\hline Building relationship with the colleague & $100 \%$ \\
\hline Communicating with the clients (patients) & $85 \%$ \\
\hline
\end{tabular}

Based on the result of questionnaire gave to the students about the interesting topic that provide in the ESP course, the table 4 can be seen that there are six topics that students' interest and all of the students' responding interest $(100 \%)$ with the topics such as giving medicine, explain medicine to client (patients), starting presentation, giving instruction for medicine, general duties of pharmacy and building relationship with the colleagues, which categorized as very important ways of learning.These findings indicate that those material should provide in the 
course of English for pharmacy.

Nevertheless, only $60 \%$ that students' responding for the topics about pronunciation which fall into enough important and description of medicine. Another topics have the same range of students' responding around 85\%, which categorized more important than pronunciation course.

Nowadays, government had banned for the people to interact each other directly. Government gave announcement for the people to reduce activity face on face because currently, the world had faced serious problem with corona virus. Because of that, this study conducted interview with the lecturer of pharmacy program at NU Sunan Giri University by phone. A lecturer as a respondent in this study is female. Based on the interview with a lecturer, the writer got the data that she saidif she teaches English program in pharmacy program by taking syllabus from internet. She using English grammar and sentence pattern are central aspects of the learning and teaching. She never asks about what the students' need and interest in the topics of English course. She just thinks if the grammar and pattern of sentence are fundamental skills that students have to master.

\section{Discussion}

Based on the table 1 in the result above, it can be seen that female respond is higher $(88 \%)$ than male respond (12\%)which means female were dominant in the class. Furthermore, all of the student in pharmacy program have been studied English program as prior knowledge. In addition, student also improving their self to practice their English in their real life (72\%) as well as frequency practicing English in more than one hours per week (52\%). That is enough for the writer to conclude that the students need to improve their English to their real life as well as future career.It similar with the Saragih (2014) that conducted research aimed to evaluate the needs of 50 nursing students in learning English. The result showed that ESP designer based on the need analysis which reflect the real of students' need.

Mastering English is one of skill that students' need in facing global era. To communicate with the foreign clients they have to be able in speaking English. Speaking skill is also can be point plus for the students to get job after finishing the study and looking for the job. It can be useful for them in future career. In their career, they can communicate well in English as tools of communication.

From the table 2 above, it shows that for the four skills in English like Listening, Reading, and Speaking and writing, there are two skill that students think still difficult to learn them, they are listening (12.2\%) and writing (9.8\%) which categorized as difficult skills. Mostly students answered that their skill are in the range fair level that almost in more than $40 \%$ in all of the skills. For the good level, mostly students answer in reading skills (63.4\%). Thus, the students need to improve their skills such as speaking, writing and especially in listening skill (9.8\%). They need to improve those skills so that they can apply in the real life and 
future career. Same as the previous study was done by Cunningham (2015) who developed reading, writing and grammar course at private language school. He found that the use of utilization-focused evaluation as part of the needs analysis was useful in that process.

The table 3 findings of this research shows that if the speaking skill that related with the real life or future career is very important for them such as interaction with the colleagues (100\%), giving advice (100\%) and presentation skill $(100 \%)$. Even the other skills like social skills, administering medication, report writing, and giving instruction effectively still become something that students think as important by seeing the data more than (70\%) in all of them.

Moreover, in the table 4 there were fifteen topics that mentions in the table, some students suggest that topic referring to clients, medicine and colleagues should be included in the English syllabus for the pharmacy program. They need the topics that related their future career and real life in their environment. Pronunciation $(60 \%)$ is one of the topics that the writer provided in the choices but mostly students interest with the topic. However, another topics still need by the students because they think useful for their life and future career.

Taaki (2006) said if needs analysis as a systematic collection and analysis of all relevant information which meet the language learning requirement of learners within the context of particular institutions involves in the learning situations. A need analysis means to get the information about students, learning needs, want, etc. Nonetheless, most of the students do not know about what they actually need. Kavaliauskiene and Uzpalience (2003) pointed out that students often find it difficult to distinguish between the needs (the skills seen as being relevant to himself/herself) and wants (the desire competence). As a lecture have to guide the students to find out what the students' need and interest.

\section{Conclusion}

Regarding to the findings and discussion, the writer put conclusion of this research.

The students' needs include academic needs and language needs. Language skills and interests include learning needs. Language skills are also used in a classroom accompanied by the questionnaire and interview to listening, speaking, writing, and reading. All four language skills are seldom used during work; listening, speaking, writing and reading. However, based on the value of English, the students employed in the hospital or aphotic realized if English is very essential for the carrier, to get more information to get a scholarship and to support an interview and a questionnaire as personal needs. The language skills required for both students and graduates are the four English skills; listening, speaking, writing and reading, which means that the lecturer must be able to increase its proportion and give the students more rehearsals during the learning process.

The real students' need and interest materials course are the fundamental reason for the writer to changing an existing English syllabus in the pharmacy 
program at NU Sunan Giri Bojonegoro. Similar with the McGrath (2002) said that makes the further point of adapting material according to what he terms as appropriacy and also to transform the learning environment into one which motivates the learner and leads to higher levels of achievement. It is hoped can help the student to get more motivation in learning English and they can get achievement in their field as well as their future career.

This research conducted in the local university at Unugiri Bojonegoro and the population of this research is the students of Unugiri while the sample of this study is pharmacy students in the second semester. For the next research, it is suggested to collaborate the research with the expert in the field like pharmacist to well-known the appropriate content of the ESP.

The writer offers proposal to utilize this prospectus for teaching English in Pharmacy for bachelor students of Pharmacy program at NU Sunan Giri Bojonegoro to develop the quality of teaching ESP program in the Unugiri.

At long last, the writer trusts that English can cover all of pharmacy intervene particle and create Indonesian pharmacist become proficient pharmacist who likewise have great English.

The curriculum should include, depending on students' needs, language requirements and learning needs, the subjects, language functions, concentration, abilities, expertise and method of teaching. In this case the curriculum should be based upon descriptions of the general tasks of pharmacist, then the practical / conceptual curriculum is appropriate for nursing students.

\section{References}

Cunningham, Robert C. (2015). Need Analysis for Development Reading, Writing, and Grammar Course at a Private Language School in Cambodia. In Second Language Studies 34(1): 1-68

Hakim, L., \& Wati, S. (2019). The Use of Lesson Writer in Developing English Teaching Materials for Vocational School Students. IDEAS: Journal on English Language Teaching and Learning, Linguistics and Literature, 7(2). doi:https://doi.org/10.24256/ideas.v7i2.1074

Hidayat, N., \& Setiawan, S. (2020). Developing Supporting Reading Materials for English Subject. IDEAS: Journal on English Language Teaching and Learning, $\begin{array}{lllll}\text { Linguistics } \quad \text { and Literature, } & 8(1), & 175 & - & 188 .\end{array}$ doi:https://doi.org/10.24256/ideas.v8i1.1335

Hutchinson, T., \& A. Waters. (1987). English for Specific Purposes A Learning-CentredApproach. Cambridge: Cambridge University Press.

Kavaliauskience, G \& Uzpalience, D. Ongoing Needs Analysis as a Factor to Successful Learning. Journal of Language Learning, 1.1 (2003)

Khoiriyah, K. (2020). CALL and SLA Theory: Developing A Framework to Analyze Web-based Materials for Teaching Listening Skills. IDEAS: Journal on English Language Teaching and Learning, Linguistics and Literature, 8(1). 
Edi Suwandi, Khoirul Wafa

Developing English Syllabus for Pharmacy Students

doi:https://doi.org/10.24256/ideas.v8i1.1296

Lukman, L. (2019). Implementing the Hidden Curriculum in EFL Classroom. IDEAS: Journal on English Language Teaching and Learning, Linguistics and Literature, 7(2). doi:https://doi.org/10.24256/ideas.v7i2.1043

McGrath, I. (2002) Materials Evaluation and Design for Language Teaching. Edinburgh: Edinburgh University Press.

P'Rayan, Albert. (2001). Engineering English: A Critical Evaluation. (Unpublished Disertation) Annamalai University

Richards, J.C. (2001). Curriculum Development in Language Teaching. Cambridge: Cambridge University Press

Richard, J.C. 2006. Communicative Language Teaching Today. Cambridge: Cambridge University Press.

Richard, J.C. (2013). Curriculum Approaches in Language Teaching. Forward, Central, and Backward Design RELC Journal. 2013.44 (1)

Saragih, Erickson. (2014). Designing ESP Materials for Nursing Students Based on Need Analysis. Internataional Journal of Linguistics Vol. 6 No. 4.

Supraba, A., Wahyono, E., \& Syukur, A. (2020). The Implementation of Reading Aloud in Developing Students' Speaking Skill. IDEAS: Journal on English Language Teaching and Learning, Linguistics and Literature, 8(1). doi:https://doi.org/10.24256/ideas.v8i1.1319

Wiersma, W \& Jurs, S. G. (2009) Research Method in Education an Introduction. Boston: Pearson International Edition

Takaaki, K. (2006). Construct Validation of a General English Language Needs Analysis Instrument. Shaken: JALT Testing and Evaluation SIG Newsletter, 10.2 